\title{
LEA-UR- $96-3610$
}

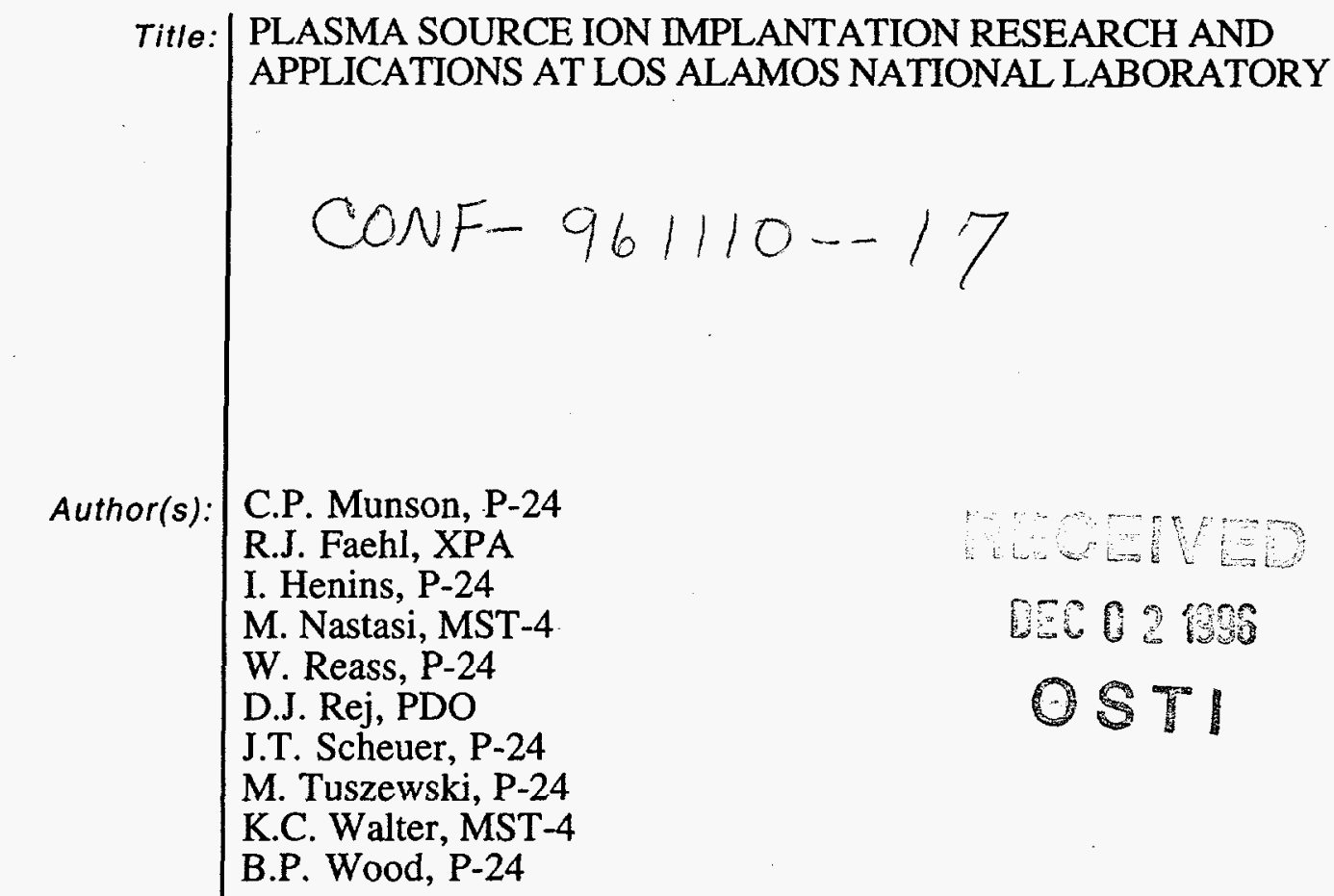

Submitted to:

14th International Conference on the Application of Accelerators in Research and Industry

November 6-9, 1996

Denton Texas

\section{Los Alamos}

NATIONAL LABOAATOAY

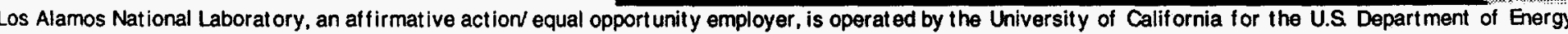

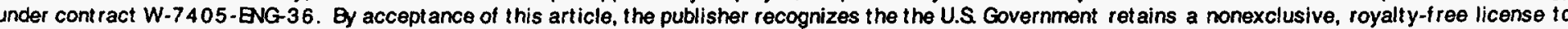

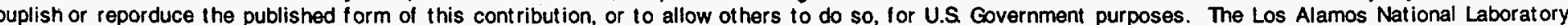
requests that the publisher ident ify this article as work performed under the auspices of the U.S. Department of energy. 


\section{DISCLAMMER}

Portions of this document may be illegible in electronic image products. Images are produced from the best available original document. 


\title{
PLASMA SOURCE ION IMPLANTATION RESEARCH AND APPLICATIONS AT LOS ALAMOS NATIONAL LABORATORY
}

\author{
C.P. Munson, R.J. Faehl, I. Henins, M. Nastasi, W. Reass, D.J. Rej, J.T. Scheuer, M. Tuszewski, \\ K.C. Walter, and B.P. Wood
}

Los Alamos National Laboratory, Los Alamos, NM 87545

\begin{abstract}
Plasma Source Ion Implantation research at Los Alamos Laboratory includes direct investigation of the plasma and materials science involved in target surface modification, numerical simulations of the implantation process, and supporting hardware engineering. Target materials of $\mathrm{Al}, \mathrm{Cr}, \mathrm{Cu}-\mathrm{Zn}, \mathrm{Mg}, \mathrm{Ni}, \mathrm{Si}, \mathrm{Ti}, \mathrm{W}$, and various $\mathrm{Fe}$ alloys have been processed using plasmas produced from $\mathrm{Ar}, \mathrm{NH}_{3}, \mathrm{~N}_{2}, \mathrm{CH}_{4}$, and $\mathrm{C}_{2} \mathrm{H}_{2}$ gases. Individual targets with surface areas as large as $\sim 4 \mathrm{~m}^{2}$, or weighing up to $1200 \mathrm{~kg}$, have been treated in the large LANL facility. In collaboration with General Motors and the University of Wisconsin, a process has been developed for application of hard, low friction, diamond-like-carbon layers on assemblies of automotive pistons. Numerical simulations have been performed using a $21 / 2-\mathrm{D}$ particle-in-cell code, which yields time-dependent implantation energy, dose, and angle of arrival for ions at the target surface for realistic geometries. Plasma source development activities include the investigation of pulsed, inductively coupled sources capable of generating highly dissociated $\mathrm{N}^{+}$ with ion densities $n_{\mathbf{i}} \sim 10^{11} / \mathrm{cm}^{3}$, at $\sim 100 \mathrm{~W}$ average input power. Cathodic arc sources have also been used to produce filtered metallic and $\mathrm{C}$ plasmas for implantation and deposition either in vacuum, or in conjunction with a background gas for production of highly adherent ceramic coatings.
\end{abstract}

\section{INTRODUCTION}

Los Alamos National Laboratory (LANL) has been actively involved in research and development efforts in the area of Plasma Source Ion Implantation (PSII), alternatively referred to as Plasma Based Ion Implantation (PBII) or Plasma Immersion Ion Implantation (PIII) $(1,2,3)$ for the past five years. These efforts have focused on the fundamental plasma and material science issues involved in PSII, as well as on the scale-up of the PSII process to industrially relevant component size and multiple component configurations. The LANL PSII facility $(4,5)$ is currently the largest known facility of its type, with an $\sim 8 \mathrm{~m}^{3}$ process chamber $(1.5 \mathrm{~m}$ diameter by $4.6 \mathrm{~m}$ long), capacatively coupled $\mathrm{RF}(13.56 \mathrm{Mhz})$ generated plasma, and a high voltage modulator capable of switching up to approximately $60 \mathrm{~A}$ of current at $120 \mathrm{kV}$. Lower voltage modulator supplies are used for the plasma based deposition of highly adherent Diamond-Like-Carbon (DLC). A smaller process chamber adjacent to the main facility is used for research and development of cathodic arc based deposition of highly adherent ceramic coatings, such as $\mathrm{Er}_{2} \mathrm{O}_{3}$. In addition to performing a significant series of test implantations for numerous industrial partners under the United States Department of Energy Defense Programs sponsored Machine Tool Partnership and LANL Laboratory Directed Research and Development programs, LANL has provided scientific support (through two Cooperative Research and Development agreements) for the small-scale commercialization of PSII for enhancement of $\mathrm{Cr}$ plating through nitrogen implantation (6).

\section{DIAMOND LIKE CARBON COATINGS}

In addition to the research and development conducted in collaboration with General Motors and the University of Wisconsin, which led to the development of a process for the application of DLC to large arrays of $\mathrm{Al}$ alloy pistons $(7,8)$, LANL has independently been involved in the investigation of the generation of adherent DLC on numerous other target materials, including $\mathrm{Mg}$ alloy AM60, Si, Ti-6Al-4V, electrodeposited hard $\mathrm{Cr}$ on 304 
stainless steel, 303, 304, 1018, 4340, A36, and M2 steels, $\mathrm{Ni}$, brass $(\mathrm{Cu}-\mathrm{Zn}), \mathrm{Cu}, \mathrm{WC}(\mathrm{Co})$, and $\mathrm{W}(9)$. Polished (mirror finish) and unpolished material samples were prepared through an initial sputter cleaning in Ar, followed by carbon implantation using $\mathrm{CH}_{4}$ gas for plasma generation, another Ar sputter step to remove graphitic carbon from the target surface, followed by DLC deposition from a $\mathrm{C}_{2} \mathrm{H}_{2}$ plasma. Experimental conditions for three experimental runs are detailed in Table 1.

TABLE 1. Processing parameters for three experimental DLC deposition runs: total target area (A), neutral fill gas pressure (p), applied pulsed bias voltage (V), voltage pulse width $(\tau)$, pulse repetition rate $(f)$, total process time for each step (T), and final DLC layer thickness (t).

\begin{tabular}{|c|c|c|c|}
\hline $\begin{array}{l}\text { process } \\
\text { step }\end{array}$ & $\begin{array}{l}\text { Run \#1 } \\
\mathrm{A} \sim 3 \mathrm{~m}^{2}\end{array}$ & $\begin{array}{l}\text { Run \#2 } \\
A \sim 0.26 \mathrm{~m}^{2}\end{array}$ & $\begin{array}{l}\text { Run \#3 } \\
A \sim 0.26 \mathrm{~m}^{2}\end{array}$ \\
\hline Ar sputter & $\begin{array}{l}\mathrm{p}=1.3 \mathrm{~Pa} \\
\mathrm{~V}=-2 \mathrm{kV} \\
\tau=20 \mu \mathrm{sec} \\
\mathrm{f}=4 \mathrm{kHz} \\
T=2.25 \mathrm{Hr}\end{array}$ & $\begin{array}{l}p=1.3 \mathrm{~Pa} \\
V=-2 \mathrm{kV} \\
\tau=30 \mu \mathrm{sec} \\
\mathrm{f}=5 \mathrm{kHz} \\
T=2.5 \mathrm{Hr}\end{array}$ & $\begin{array}{l}\mathrm{p}=1.3 \mathrm{~Pa} \\
\mathrm{~V}=-2 \mathrm{kV} \\
\tau=30 \mu \mathrm{sec} \\
\mathrm{f}=5 \mathrm{kHz} \\
\mathrm{T}=2.2 \mathrm{Hr}\end{array}$ \\
\hline $\begin{array}{l}\text { carbon } \\
\text { implant } \\
\left(\mathrm{CH}_{4}\right)\end{array}$ & $\begin{array}{l}\mathrm{p}=0.04 \mathrm{~Pa} \\
\mathrm{~V}=-20 \mathrm{kV} \\
\tau=20 \mu \mathrm{sec} \\
\mathrm{f}=700 \mathrm{~Hz} \\
\mathrm{~T}=4.75 \mathrm{Hr}\end{array}$ & no implant & $\begin{array}{l}\mathrm{p}=0.07 \mathrm{~Pa} \\
V=-50 \mathrm{kV} \\
\tau=20 \mu \mathrm{sec} \\
\mathrm{f}=2 \mathrm{kHz} \\
T=1.2 \mathrm{Hr}\end{array}$ \\
\hline Ar sputter & $\begin{array}{l}\mathrm{p}=1.3 \mathrm{~Pa} \\
\mathrm{~V}=-2 \mathrm{kV} \\
\tau=20 \mu \mathrm{sec} \\
\mathrm{f}=4 \mathrm{kHz} \\
T=8 \mathrm{~min}\end{array}$ & no sputter & $\begin{array}{l}\mathrm{p}=1.3 \mathrm{~Pa} \\
\mathrm{~V}=-2 \mathrm{kV} \\
\tau=30 \mu \mathrm{sec} \\
\mathrm{f}=5 \mathrm{kHz} \\
\mathrm{T}=10 \mathrm{~min}\end{array}$ \\
\hline $\begin{array}{l}\text { DLC } \\
\text { deposit } \\
\left(\mathrm{C}_{2} \mathrm{H}_{2}\right)\end{array}$ & $\begin{array}{l}\mathrm{p}=0.07 \mathrm{~Pa} \\
\mathrm{~V}=-1.5 \mathrm{kV} \\
\tau=20 \mu \mathrm{sec} \\
\mathrm{f}=4 \mathrm{kHz} \\
\mathrm{T}=48.5 \mathrm{Hr}\end{array}$ & $\begin{array}{l}\mathrm{p}=0.05 \mathrm{~Pa} \\
\mathrm{~V}=-1.5 \mathrm{kV} \\
\tau=30 \mu \mathrm{sec} \\
\mathrm{f}=5 \mathrm{kHz} \\
\mathrm{T}=3.5 \mathrm{Hr}\end{array}$ & $\begin{array}{l}\mathrm{p}=0.04 \mathrm{~Pa} \\
\mathrm{~V}=-1.5 \mathrm{kV} \\
\tau=30 \mu \mathrm{sec} \\
\mathrm{f}=5 \mathrm{kHz} \\
\mathrm{T}=3.5 \mathrm{Hr}\end{array}$ \\
\hline $\begin{array}{l}\text { DLC } \\
\text { thickness }\end{array}$ & $\mathrm{t}=6.8 \mu \mathrm{m}$ & $\mathrm{t}=0.5 \mu \mathrm{m}$ & $\mathrm{t}=0.3 \mu \mathrm{m}$ \\
\hline
\end{tabular}

Each of these experimental runs produced a DLC coating with $\sim 70 \%$ (atomic) $\mathrm{C}, 30 \%$ (atomic) $\mathrm{H}$, and having a hardness (measured using a Nanoindenter ${ }^{\circledR}$ II (10)) of $20 \mathrm{Gpa}$. Ion beam analysis $(11,9)$ of W samples (untreated, implanted, and unimplanted) demonstrated the generation of a graded layer (mixed $\mathrm{C}$ and $\mathrm{W}$ ) approximately $50 \mathrm{~nm}$ thick between the base $\mathrm{W}$ and the DLC layer for the implanted sample. A graded region of this type is not present for the unimplanted or untreated samples.

DLC adhesion measurements were performed using a Sebastian ${ }^{\circledR}$ II (12) stud pull test, and by examination of Scanning Electron Microscope (SEM) micrographs of the adhesion test areas. Table 2 summarizes the adhesion testing results.

TABLE 2. Adhesion test results. DLC layers which delaminated from the substrate material after exposure to air are indicated as "Not Adherent".

\begin{tabular}{|l|l|l|l|}
\hline $\begin{array}{l}\text { Coating } \\
\text { Behavior }\end{array}$ & $\begin{array}{l}\text { Run \#1 } \\
\text { (implant) }\end{array}$ & $\begin{array}{l}\text { Run \#2 } \\
\text { (no implant) }\end{array}$ & $\begin{array}{l}\text { Run \#3 } \\
\text { (implant) }\end{array}$ \\
\hline Adherent & $\mathrm{M} 2,4340$, & $\mathrm{Mg}, \mathrm{Al}, \mathrm{Cr}$, & $\mathrm{Mg}, \mathrm{Al}, \mathrm{Cr}$, \\
& 1018,303, & 304, & 304, \\
& $\mathrm{Cr}, \mathrm{Si}, \mathrm{Al}$ & $\mathrm{WC}(\mathrm{Co})$, & $\mathrm{WC}(\mathrm{Co})$, \\
& & $\mathrm{Si}, \mathrm{M} 2, \mathrm{~W}$, & $\mathrm{Si}, \mathrm{M} 2, \mathrm{~W}$, \\
& & $\mathrm{A36,}$ & $\mathrm{Ni}$, \\
& & Ti-6Al-4V, & $\begin{array}{l}\text { Ti-6Al-4V, } \\
\text { brass }\end{array}$ \\
\hline $\begin{array}{l}\text { Not } \\
\text { Adherent }\end{array}$ & $\mathrm{Ti}$ & $\mathrm{Cu}$, brass, Ni & $\mathrm{Cu}, \mathrm{A36}$ \\
\hline
\end{tabular}

It is postulated that the lack of adherence to the $\mathrm{Ti}$ sample from Run \#1 is due to insufficient initial cleaning of the surface (this sample was machined, rather than polished), and that the A36 sample from Run \#3 was not in good thermal contact with the support substrate during implantation - resulting in sample heating, and changes in the DLC deposition process. SEM analysis combined with the adhesion test results demonstrates that enhanced DLC adhesion can be achieved by appropriately using ion implantation to produce a carbon graded interface between the base material and the DLC layer.

\section{NITROGEN IMPLANTATION}

Nitrogen implantation has been proven to be an effective mechanism for improving the surface hardness and wear characteristics of a range of metals and metal alloys when performed either at room, or elevated temperatures (7). By utilizing either $\mathrm{N}_{2}$, or $\mathrm{NH}_{3}$ gas for plasma production, nitrogen implantation is routinely performed in the LANL PSII facility on test targets ranging from very small assemblies of material samples $\left(-0.03 \mathrm{~m}^{2}\right.$ surface area $)$ to large components or component assemblies with total surface areas approaching $4 \mathbf{m}^{2}$. The choice between $\mathbf{N}_{2}$ and $\mathrm{NH}_{3}$ is driven by considerations of the potential impact of a significant hydrogen content within the plasma, versus the increased implantation depth which can be obtained when using $\mathrm{NH}_{3}$ at a given applied implantation voltage. (The $\mathrm{N}$ implanted from $\mathrm{NH}_{3}$ has approximately 1.65 times the energy of $\mathrm{N}$ implanted from $\mathrm{N}_{2}$, assuming that the plasma conditions are such that the dominant species in each case is the singly ionized molecular state.) Small test targets $\left(\sim 0.03 \mathrm{~m}^{2}\right)$ can be implanted at controlled, elevated temperatures, by eliminating the active stage cooling normally employed, 
and utilizing an IR temperature monitor viewing a cavity in the target substrate as a feedback control signal for the implantation voltage pulse frequency (5). Implantation into a stainless steel alloy similar in composition to SS321, using $\mathrm{N}_{2}$ as the plasma source gas, at a temperature of $325^{\circ} \mathrm{C},-30 \mathrm{kV}$ pulse voltage, $20 \mu \mathrm{sec}$ pulse duration, for 1.25 hours (varying pulse repetition frequency, estimated incident dose $\sim 10^{18} \mathrm{~N}-\mathrm{at} / \mathrm{cm}^{2}$ ) resulted in a retained dose (measured by means of non-Rutherford backscattering $(13,14))$ of $6 \times 10^{17} \mathrm{~N}-a t / \mathrm{cm}^{2}$, with significant $\mathrm{N}$ present at a depth of $540 \mathrm{~nm}$. Typical nitrogen implants of large surface area targets (up to $\sim 4 \mathrm{~m}^{2}$, component weights as large as $\sim 1200 \mathrm{~kg}$ to date) are performed in the LANL facility at room temperature utilizing active target cooling, applied voltages exceeding $-45 \mathrm{kV}$, and an incident $\mathrm{N}$ dose of from $\sim 5 \times 10^{17}$ to $\sim 1 \times 10^{18} \mathrm{~N}$-at $/ \mathrm{cm}^{2}$. Results are highly application dependent, and range from an insignificant change in performance, to component lifetime improvements up to almost an order of magnitude. With $\mathrm{Cr}$ plated components, for which large lifetime improvements have been observed in some cases, an additional benefit is the possible reduction in the hazardous waste stream associated with the $\mathrm{Cr}$ plating process.

\section{CATHODIC ARC APPLICATIONS}

As part of the Department of Energy Defense Programs Fire Resistant Pit project, research on the combination of cathodic (or vacuum) arc metal plasma sources $(15,16)$ with PSII techniques has been conducted for the generation of highly adherent coatings of $\mathrm{Er}_{2} \mathrm{O}_{3}$ (erbia) on steel alloys (17). Erbia is a ceramic material which is highly resistant to attack by molten plutonium, which forms relatively low melting point eutectics with many other metals. Highly adherent erbia layers of appropriate thickness could be used to reduce the waste stream produced during plutonium metallurgical work by effectively isolating the molten $\mathrm{Pu}$ from other materials, and to enhance the environmental safety of the nuclear weapons stockpile. Adherent erbia layers up to $\sim 4 \mu \mathrm{m}$ have been produced at LANL by these techniques, and are being investigated for their utility in resisting attack by molten metals.

\section{COMPARISON OF NUMERICAL SIMULATIONS AND EXPERIMENTAL RESULTS OF IMPLANTATION}

Numerical simulations have been performed using a 2 1/2-D particle-in-cell code, which yields time-dependent implantation energy, dose, and angle of arrival for ions at the target surface for realistic target geometries (18). By using a target assembly composed of vertical columns of pistons supported by horizontal cooling/support bars (19) as a complex substrate for the implantation of Mo coupons, a comparison of the numerical code results with the retained dose was obtained (5). One of the columns of pistons was removed from the center of the assembly before the $\mathrm{N}$ implantation, and Mo coupons were placed on the outer faces of pistons, in the inter-column regions of normally spaced columns $(\sim 12 \mathrm{~cm}$ spacing), and in the central region from which a column had been removed $(\sim 32 \mathrm{~cm}$ column spacing). For the plasma conditions used during the implantation, a maximum plasma sheath thickness of $\sim 28 \mathrm{~cm}$ was calculated, which indicates severe sheath overlap between the normally spaced columns, and moderate sheath overlap in the central region. The measured retained dose in the Mo coupons within the central region was reduced by a factor of $\sim 2.4$ below the retained dose in the fully exposed Mo coupons, and the retained dose for the coupons in the narrower inter-column regions was reduced by a factor of $\sim 3.7$. These results are in reasonable agreement with the incident dose reductions predicted by the numerical code for similarly shielded positions.

\section{PLASMA SOURCE DEVELOPMENT}

The capacatively coupled RF plasma source routinely used in the LANL facility produces relatively low plasma densities in the range of $\sim 5 \times 10^{14} / \mathrm{m}^{3}$ to $\sim 3 \times 10^{15} / \mathrm{m}^{3}$. This range is, however, reasonably consistent with the constraints imposed by the present modulator output current capability and the desire to successfully implant large surface area targets (4). In order to efficiently achieve higher plasma densities, and at the same time gain some control over the ionic species present in the plasma (i.e. $\mathrm{N}^{+}$vs $\mathrm{N}_{2}{ }^{+}$), research has been conducted in the utilization of pulsed, inductively coupled plasma sources $(20,6)$. Pulsed sources of this type are capable of generating high plasma densities (as high as $10^{17} / \mathrm{m}^{3}$ ) at low gas pressures, and with relatively low average power requirements (hundreds of Watts). High instantaneous power dissipated during the pulse ( $10 \mathrm{~s}$ of $\mathrm{kW})$, however, can lead to a much greater production of ionized atomic species $\left(N^{+}\right)$as opposed to the molecular species $\left(\mathrm{N}_{2}{ }^{+}\right)$ which predominates the capacatively coupled $\mathrm{RF}$ generated plasma. Additional tailoring of the ionic species may be achieved through adjusting the timing between the pulsed plasma production, and the application of the implantation voltage to the target $(6,20)$. Higher plasma densities lead to more conformal plasma sheaths, and more uniform implantation of complex, small feature size, targets. The higher density places much more severe demands on the modulator, since the required modulator current is proportional to the plasma density (target area and applied voltage being held constant). 


\section{MODULATOR ENGINEERING}

In addition to continuing the use and development of vacuum switch tube based modulators for PSII, LANL is conducting LDRD and DOE/DP supported development of modulators based on solid state Insulated Gate Bipolar Transistor (IGBT) devices. Present generation IGBTs are capable of rapidly switching $\mathrm{kA}$ and $\mathrm{kV}$ level currents and voltages for single units, and can be operated in series or parallel in properly designed systems to provide increased total current and voltage handling capabilities. Moderately sized IGBT based systems switching $\sim 1 \mathrm{kA}$ of current at $\sim 20 \mathrm{kV}$ could be used to drive a pulse transformer, producing $\sim 100 \mathrm{kV}$ at $200 \mathrm{~A}$.

\section{SUMMARY}

Research programs at LANL continue to address essentially all aspects of the development of PSII for potential applications both within the DOE/DOD complex, and within industry. Basic plasma physics, materials science, and systems engineering issues are all addressed in an integrated fashion.

\section{ACKNOWLEDGMENTS}

The authors would like to thank the Ion Beam Materials Laboratory, Los Alamos National Laboratory, for assistance with the ion beam analysis. This work has been supported by the United States Department of Energy through the Office of Basic Energy Sciences, US DOE Defense Programs, and through the Los Alamos National Laboratory - Laboratory Directed Research and Development program.

1. R. Adler, Nucl. Instr. Methods, B6, p. 123 (1985).

2. J.R. Conrad and K. Sridharan (eds.), Papers from the First International Workshop on Plasma-Based Ion Implantation, (Journal of Vacuum Science and Technology B), V. 12 (\#2) (1994).

3. G.A. Collins (ed.), Proceedings of the Second International Workshop on Plasma-Based Ion Implantation, 1995, Surface Coatings and Technology, in press

4. B.P. Wood, I. Henins, R.J. Gribble, W.A. Reass, R.J. Faehl, M.A. Nastasi, and D.J. Rej, J. Vac. Sci. Technol., B 12, 870 (1994).

5. C.P. Munson, R.J. Faehl, I. Henins, M. Nastasi, W.A. Reass, D.J. Rej, J.T. Scheuer, K.C. Walter, and B.P. Wood, "Recent Advances in Plasma Source Ion Implantation at Los Alamos National Laboratory", to be published in Surface and Coatings Technology,
Proceedings of the 9th International Conference on the Surface Modification of Metals by Ion Beams, San Sebastian, Spain, Sept. 4-8, 1995.

6. J. T. Scheuer, R. A. Adler, and W. G. Horne, "A Commercial Plasma Source Ion Implantation Facility", presented at the 3rd International Workshop on Plasma-Based Ion Implantation, Dresden, Germany, Sept. 15-18, 1996 (to be published in Surface Coatings and Technology).

7. J.V. Mantese, I.G. Brown, N.W. Cheung, and G.A. Collins, Materials Research Society Bulletin, V. 21(\#8), 52-56 (1996)

8. G.W. Malaczynski, Xiaohong Qiu, J.V. Mantese, A.A. Elmoursi, A.H. Hamdi, B.P. Wood, K.C. Walter, and M.A. Nastasi, US Patent $5,458,927$

9. K.C. Walter, M. Nastasi, and C. Munson, "Adherent Diamond-Like Carbon Coatings on Metals via Plasma Source Ion Implantation", presented at the 3rd International Workshop on Plasma-Based Ion Implantation, Dresden, Germany, Sept. 15-18, 1996 (to be published in Surface and Coatings Technology).

10. Nano Instruments, Inc., Knoxville, TN.

11. J.R. Tesmer and M.A. Nastasi (eds.), Handbook of Modern Ion Beam Materials Analysis, Pittsburg, PA: Materials Research Society, 1995, pp. 83,498.

12. The Quad Group, Spokane, WA.

13. J. Tesmer and M.A. Nastasi (eds.), Handbook of Modern Ion Beam Analysis, Pittsburgh, PA: Materials Research Society, 1995.

14. L.A. Foster, J.R. Tesmer, T.R. Jervis, and M.A. Nastasi, Nucl. Instr. Meth. in Phys. Res. B79, p. 454, (1993).

15. P.C. Johnson, in J.L. Vossen and W. Kern (eds.), Thin Film Processes II, Boston: Academic Press, Inc., 1991, p. 218.

16. J.M. Lafferty (ed.), Vacuum Arcs - Theory and Applications, New York: Wiley, 1980.

17. B.P. Wood, W.A. Reass, and I. Henins, in Proceedings of the Second International Workshop on Plasma-Based Ion Implantation, Sydney, Australia, 1995, (to be published in Surface Coatings and Technology).

18. R. Faehl, J. Vac. Sci. Tech., B12, p. 884 (1994).

19. cover photo, MRS Bulletin, V21 (\#8), (1996).

20. M. Tuszewski, J.T. Scheuer, and R.A. Adler, "A Pulsed Inductively Coupled Plasma Source for PlasmaBased Ion Implantation", submitted to Surface Coatings Technology. 